\title{
DETERMINATION OF THE PLASMA GLYCINE AFTER GELATIN FEEDING AS A DIAGNOSTIC PROCEDURE FOR PANCREATIC FIBROSIS
}

\author{
BY HALVOR N. CHRISTENSEN AND HARRY SHWACHMAN \\ (From the Division of Laboratories, The Children's Medical Center, Boston, and Departments \\ of Biological Chemistry, and Pediatrics, Harvard Medical School, Boston)
}

(Received for publication November 1, 1948)

A retardation of the absorption of amino acids derived from ingested protein into the bloodstream is known to result from a failure of the secretion of the pancreatic proteinases. West, Wilson and Eyles (1) have shown that a much smaller rise in blood amino nitrogen occurs in children with pancreatic fibrosis than in normal children after a test meal of casein. Preliminary results obtained by these authors indicated that gelatin might be a better test protein. To avoid a choice between the technically somewhat complex manometric ninhydrin procedure (Hamilton and Van Slyke [2]) and the analytically unsatisfactory colorimetric amino nitrogen methods (cf. Chinard and Van Slyke [3]) we have determined the plasma concentration of the single amino acid, glycine. Advantage is taken of the convenient method available for glycine (Alexander, Landwehr and Seligman [4]), the high glycine content of gelatin $(25.5 \%)$, and the relatively slow disposition of this amino acid. Comparison of the fasting plasma glycine with the level 150 minutes after gelatin feeding provides a simple diagnostic procedure, although some qualifications will be noted below.

Although duodenal intubation in most cases is not a difficult procedure, upon occasion it may be troublesome. Mention might be made of $a$ ) several instances where four or five separate unsuccessful attempts were made to obtain a satisfactory specimen from a patient, $b$ ) the undesirability of the procedure in the severely ill infant, and $c$ ) the occasional febrile reaction following intubation. The present procedure offers an alternative diagnostic test.

\section{EXPERIMENTAL}

The test procedure is as follows: the patient is given, six to 12 hours after the last meal, 1.5 grams of protein per kilogram of body weight in the form of Knox gelatin, in $30 \mathrm{ml}$. of warm water per kilograms, either by mouth or by gavage. Venous blood is collected just before the feeding and $21 / 2$ hours after. The plasma is separated at once, deproteinized with picric acid, and the glycine determined according to Alexander et al. (4). The analysis depends upon a colorimetric measure of the formaldehyde released from glycine by ninhydrin. A comparison of the optical densities of the two samples without translating them into glycine concentrations is sufficient.

For the deproteinization, 5 volumes of picric acid are added to the plasma, and the mixture centrifuged (Hamilton and Van Slyke [2]). When analyzing fasting blood, a $4 \mathrm{ml}$. aliquot of plasma filtrate is used; for the samples taken later, $2 \mathrm{ml}$. usually give a suitable depth of color. This means that 3 or $4 \mathrm{ml}$. of fasting blood and $1.5 \mathrm{ml}$. of the postprandial blood samples permit duplicate analyses. The requirements can be decreased if necessary to about $0.5 \mathrm{ml}$. of blood by cutting quantities used in half throughout the procedure, and distilling over to a volume of $5 \mathrm{ml}$. rather than $10 \mathrm{ml}$. A drop of normal sodium hydroxide is added for each $2 \mathrm{ml}$. of picric acid filtrate used in the determination, to neutralize the picric acid.

The patients studied ranged from one month to 12 years in age. In most cases the plasma glycine was determined before the test, and one and $2 \frac{1 / 2}{2}$ hours after the test meal. The total $\alpha$-amino nitrogen in many cases was also determined for comparison.

\section{RESULTS AND BISCUSSION}

Three groups of patients were studied:

1. Twenty-four patients for whom the diagnosis of pancreatic fibrosis had been established, in 22 of them by the absence of tryptic activity in the duodenal contents.

2. Nineteen patients for whom the diagnosis of pancreatic fibrosis had been excluded. These were malnourished children, several of whom suggested the diagnosis of pancreatic fibrosis on clinical grounds.

3. Six patients whose clinical course was consistent with the diagnosis of pancreatic fibrosis, who had, however, definite although diminished tryptic activity. 


\section{TABLE I}

The plasma glycine nitrogen following gelatin feeding

The values are averages for the group of patients indicated, and are in $\mathrm{mg}$. $\mathrm{N}$ per $100 \mathrm{ml}$.

\begin{tabular}{|c|c|c|c|c|c|}
\hline & \multirow{2}{*}{$\begin{array}{c}\text { Fast- } \\
\text { ing }\end{array}$} & \multirow{2}{*}{$\begin{array}{l}\text { In- } \\
\text { crease } \\
\text { after } \\
60 \\
\text { min. }\end{array}$} & \multirow{2}{*}{$\begin{array}{l}\text { In- } \\
\text { crease } \\
\text { after } \\
150 \\
\text { min. }\end{array}$} & \multicolumn{2}{|c|}{$\begin{array}{l}\text { Ratio, } 150 \mathrm{~min} . \\
\text { to fasting }\end{array}$} \\
\hline & & & & Mean & Range \\
\hline $\begin{array}{l}\text { Controls (19) } \\
\text { Pancreatics (24) } \\
\text { Pancreatics + pan- } \\
\text { creatin (8) }\end{array}$ & $\begin{array}{l}0.26 \\
0.32 \\
0.33\end{array}$ & $\begin{array}{l}0.90^{*} \\
0.44 \dagger \\
1.37\end{array}$ & $\begin{array}{l}1.28 \\
0.59 \\
1.18\end{array}$ & $\begin{array}{l}5.0 \\
1.9 \\
3.6\end{array}$ & $\begin{array}{l}2.6 \text { to } 7.6 \\
1.2 \text { to } 3.2 \\
2.6 \text { to } 5.3\end{array}$ \\
\hline
\end{tabular}

* Average includes only 13 cases.

† Average includes only 14 cases.

To the first two groups of patients the following generalization could be applied, with two exceptions to be discussed later.

Patients without tryptic activity have their plasma glycine increased up to 2.5 times the fasting level (mean, 1.9 times) ; patients with good tryptic activity have their glycine increased by 2.6 to 7.6 times (mean, 5.0 times) 150 minutes after the test meal (Table I).

Similarly these patients could be divided into the same two groups by the rise in the plasma $\alpha$ amino nitrogen in the 17 cases where this determination was made (Table II). Seven patients given pancreatin (coated granules) with the gelatin had their glycine and $\alpha$-amino nitrogen tolerance curves moved from the deficient to the high normal range. The results were similar whether gelatin was fed by mouth or introduced by tube directly into the stomach or duodenum.

Included in the group of 24 patients with no significant pancreatic enzymatic activity, were three patients showing rather high glycine responses, one so high on two of three occasions as to represent a striking exception. These patients all, inci- dentally, had a diagnosis of meconium ileus at birth. The ratios of the plasma glycine levels after and before gelatin were: R. E., 2.5 ; M. M., 3.2; and D. B., 4.1, 5.7, and 3.0. The last patient had hepatic disease (probably homologous serum jaundice) more severe at the time of the first two tests than at the time of the third test. Since the plasma glycine level undoubtedly represents a balance between the relative rates of the absorption and of the disposal of glycine, severe hepatic disease may be a complicating factor in this test.

The third group consisted of the six patients who presented relatively low yet quite definite tryptic activity in their duodenal contents. The ratio of final to original glycine levels were as follows : D. R., 2.2 ; A. O., 2.4 ; S. F., 2.9 ; F. M., 3.2 ; R. V., 3.8; P. N., 5.7. Three of these values are above the range obtained for patients having no significant amount of tryptic activity. That a group of children showing intermediate degrees of pancreatic enzyme activity should range rather widely in their rates of gelatin digestion is not surprising. Heretofore partial pancreatic insufficiency, in patients with the clinical appearance of pancreatic fibrosis, has not been described. This group is under study.

Finally, a single patient was observed who had normal enzymatic activities in his duodenal fluid, but who showed a rise to only 1.9 times his fasting plasma glycine after his test meal. This patient could absorb glycine no better when pancreatin was fed with the gelatin, or even when the glycine was fed in the free state. Since children with pancreatic disease absorbed glycine readily in either of the last two situations, clearly this is a different type of deficiency, and accordingly this patient is not included in the general averages.

TABLE II

The plasma a-amino nitrogen following gelatin feeding

The concentrations are in milligrams per $100 \mathrm{ml}$.

\begin{tabular}{|c|c|c|c|c|c|c|c|c|}
\hline & \multirow{2}{*}{\multicolumn{2}{|c|}{ Fasting }} & \multicolumn{4}{|c|}{ Increase } & \multirow{2}{*}{\multicolumn{2}{|c|}{$\begin{array}{l}\text { Ratio, higher level } \\
\text { to fasting level }\end{array}$}} \\
\hline & & & \multicolumn{2}{|c|}{ After $60 \mathrm{~min}$} & \multicolumn{2}{|c|}{ After $150 \mathrm{~min}}$. & & \\
\hline & Mean & Range & Mean & Range & Mean & Range & Mean S.D. & Range \\
\hline $\begin{array}{l}\text { Controls (10) } \\
\text { Pancreatics (7) } \\
\text { Pancreatics + pan- } \\
\text { creatin (6) }\end{array}$ & $\begin{array}{l}3.55 \\
3.38 \\
3.23\end{array}$ & $\begin{array}{l}2.90 \text { to } 4.54 \\
2.89 \text { to } 4.05 \\
2.55 \text { to } 4.81\end{array}$ & $\begin{array}{l}2.31 \\
0.32 \\
4.04\end{array}$ & $\begin{array}{r}0.60 \text { to } 4.48 \\
-0.37 \text { to } 1.10 \\
3.02 \text { to } 5.35\end{array}$ & $\begin{array}{l}3.51 \\
0.57 \\
3.65\end{array}$ & $\begin{array}{r}1.49 \text { to } 6.22 \\
-0.78 \text { to } 1.35 \\
2.10 \text { to } 5.33\end{array}$ & $\begin{array}{l}2.0 \pm 0.3 \\
1.2 \pm 0.2 \\
2.3 \pm 0.4\end{array}$ & $\begin{array}{l}1.43 \text { to } 2.50 \\
0.93 \text { to } 1.40 \\
1.82 \text { to } 2.92\end{array}$ \\
\hline
\end{tabular}


The subject also yielded a flat glucose tolerance curve.

Apparently a further test is desirable for an occasional patient to determine whether or not pancreatin intensifies significantly the elevation of the plasma glycine produced by gelatin feeding. Not only will this permit detection of the probably rare patient who cannot absorb readily even free glycine, but should also assist in clarifying the status of subjects who may show equivocal responses.

\section{SUMMARY}

1. Forty-nine patients presenting symptoms of malnutrition and respiratory disease suggesting a diagnosis of pancreatic fibrosis have been studied as to the response of their plasma glycine concentrations to the feeding of gelatin.

2. Twenty-two out of 24 patients having no significant tryptic activity in their duodenal fluid showed rises to not more than 2.5 times their fasting glycine levels. Nineteen patients having good pancreatic enzyme activity showed increases to more than 2.5 times the fasting value (average, five times fasting level). Liver disease may have been a factor in the exceptional increases shown by one of the patients with pancreatic disease.

3. The feeding of pancreatin with the gelatin changed the responses of either the glycine or $\alpha$ - amino nitrogen from the pancreatic-deficient range to the high normal range.

4. A group of six patients showing definite, although small, tryptic activity in their duodenal fluids gave rather widely ranging responses to the test.

5. A single patient presenting evidence of normal secretion of pancreatic enzymes absorbed glycine poorly even when the amino acid was fed in the free state.

The assistance of Miss Jean Streicher is gratefully acknowledged.

\section{BIBLIOGRAPHY}

1. West, C. D., Wilson, J. L., and Eyles, R., Blood amino nitrogen levels. Am. J. Dis. Child., 1946, 72, 251.

2. Hamilton, P. B., and Van Slyke, D. D., The gasometric determination of free amino acids in blood filtrates by the ninhydrin-carbon dioxide method. J. Biol. Chem., 1943, 150, 231.

3. Chinard, F. P., and Van Slyke, D. D., Comparison of a modified Folin photometric procedure and the ninhydrin manometric method for the determination of amino acid nitrogen in plasma. J. Biol. Chem., 1947, 169, 571.

4. Alexander, B., Landwehr, G., and Seligman, A. M., A specific micromethod for the colorimetric determination of glycine in blood and urine. J. Biol. Chem., 1945, 160, 51. 